\title{
Creating a New Strategy-Model: Customer Differentiation and Co-Creation Leading to Sustainable Growth
}

\author{
Roos, R., Stoffers, J. \\ Research Centre of Employability, Zuyd University of Applied Sciences, Heerlen-Maastricht-Sittard, the Netherlands
}

Email address:

jol.stoffers@zuyd.nl (Stoffers, J.)

To cite this article:

Roos, R., Stoffers, J.. Creating a New Strategy-Model: Customer Differentiation and Co-Creation Leading to Sustainable Growth. Science Journal of Business and Management. Vol. 3, No. 4, 2015, pp. 95-101. doi: 10.11648/j.sjbm.20150304.11

\begin{abstract}
In this review article we elaborate on three important mechanisms in order to create a new (holistic) strategymodel: market orientation, service dominant logic, and co-creation of value. We have reasoned on the central premise that in order to create sustainable business growth in the firm, this firm needs to structure itself in a way that optimises solution selling, customer focus and value co-creation. Employees in all departments of the firm need to have a change of mind-set, from delivering goods towards delivering service proposals, and therefore establishing context to the set strategy. In order to act upon these service innovations, the modifications are dependent on a collection of competences, which the firm needs to continually renew, create, integrate, and transform.
\end{abstract}

Keywords: (Holistic) Strategy-Model, Customer Differentiation, Co-Creation

\section{Introduction}

What is strategy? This simple yet justified question is what managers and scholars have been working on throughout time. Strategy does not only depend on content, but, far more importantly, on context. There are multiple strategic solutions to a specific issue, but they might vary depending on the context of the argument [1]. Actions that are successful for some companies might not work for others, due to different environmental circumstances, both internal as well as external. Taking this argumentation into account we see, over the years, that in many firms managers or executives have been trying to amend strategic thinking and effectuation within the same structure of their predecessors [2]. This is, in principle, forging ahead on things that might not work anymore, due to different contexts of the business or external environment. Although many firms claim to be engaged in strategy and innovation in order to create a sustainable environment for them to grow in modern business life; in actuality, not many of them also have the right internal assets and mind-set to be successful. They remain product-minded, and see this as the main attribute of competitive advantage [3]. The principle of strategy is already prominent for many years in academic literature, as well in annual plans of firms. Still, there are limited companies worldwide that have, to our view, a successful strategy and mind-set integrated into their organisational culture. Although, due to the circumstances surrounding the economic crises of the past couple of years, the outside-in mentality is winning ground as the denominator to create sustainable competitive advantage. What firms lack, however, is the ability to transform their internal structure and thinking, as well as the way employees operate within this changed notion leading to a firm and customer-based sustainable strategy and output [4]. There are clear indicators, though, that the world of business is changing from an industrial-based society into an environment that is actually knowledge driven; by building on professionals and their expertise, and engaging in collaboration with customers in a search to create value together.

In our opinion a strategy has to be implemented on product group level that identifies the opportunities in the market, and targets specific customer groups' needs by providing solution determined marketing. This means combining a market orientation with service-based logic, and collaboration with the customer, in order to create a competitive advantage for the firm. In this review article we will work on the expressed, personal view that organisations need to base their strategies on this combination, if they are willing to succeed in a changing business environment. Firms need to show that they are bringing additional value to the table when engaging with customers in order to win business [5]. We believe that the mind set combining the elements at play within market 
orientation and service determined marketing could give corporations, this competitive edge.

In order to succeed sustainably, firms need to adopt a different mind set, deferring from putting goods as the central output mechanism into having service, and therefore resources, as the central mechanism [4]. However, this does mean that there needs to be a mind shift implemented at all stakeholders, both internally and externally. In order to deliver superior value to customers, and also incorporate them into the value creation process, firms need to know exactly what resources they possess, and more importantly, what resources their customers need [4]. In short, there are three important mechanisms when implementing such a strategy: market orientation, service dominant logic, and cocreation of value. Having these three operations incorporated into the organisation, to the level that is desired from the business the corporation is in, will lead to beneficial organisational output, and therefore financial gains and sustainable value and growth creation. Taking this notion as the central approach for establishing the new strategy-model, these theories will be our basis for the development of this framework. In this review article, we will explain the three principles in more detail, with emphasis on the role of employees' mind-set and competences, and conclude that we believe this will impact the establishment of the new strategy-model.

\section{Towards a New (Holistic) Strategy- Model}

\subsection{Market Orientation}

Porter [6] stated that a firm's economical success is based on developing a sustainable, competitive advantage, which is consistently creating superior value for customers [7]. This means that, in the long run, an organisation can only generate sustainable growth by providing superior value to customers, compared to the competition. Business', therefore, need to be more customer-centric, as technology has evolved to allow the lower cost provision of information and customer solutions. In order to respond in a correct manner, the strategic business model defines how the enterprise creates and delivers value to customers, and then converts payments received to profits [8]. Following this statement, researchers have observed that the disposition of value creation increasingly extends traditional firm boundaries $[9,10,11]$. These notions mean that the mere focus cannot be on products anymore, but has to shift towards a customer focus. In the marketing and strategy literature this shift has been marked as market orientation, which entails organisations having their view towards pulling market circumstances into the firm, i.e. customers, competition and opportunities. The rationale underlying the high profiling of a customer focal point is the marketing concept, which promotes putting the interests of the customer first [12]. Market orientation characterizes an organisation's disposition to continuously deliver superior value to its customers [13]. Still, in this view there should be a balanced mix between customer and competition orientation, in order to gain a competitive advantage [14]. At the moment, market orientation is not yet commonly proposed as a customer-defined organisation state or strategy throughout businesses [15]. Nevertheless, the development of market orientation is a necessary prerequisite [16]. If firms are not increasingly engaged into satisfying customers' needs in a superior manner than the competition, sustainable presence or growth cannot be assured. Although, it is the customers' perception of the level to which a firm is customer oriented that will be the critical measure of business performance [12].

According to Webb et al. [15], an organisation can only be described as market oriented when the firm's total product offer is both recognised and described by customers in value terms. If a company is market oriented, three characteristics must be evident. First, information on salient buying influences should permeate each corporate function. Second, strategic and tactical decisions need to be made interfunctionally and inter-divisionally. Third, divisions and functional units need to make coordinated decisions and execute them with a sense of commitment [17]. This last notion builds on the premise stated by Zaltman, Duncan, and Holbek [18], that when functions are integrated across departments in an organisation, the problem-solving capabilities are potentially enhanced by the individuals working towards a common goal. This notion entails an organisation-wide commitment to continuous information gathering, coordination of customer needs, competitor's capabilities, and the provision of other significant market agents [19]. Installing a firm-based market orientation builds upon the claim that market orientation establishes three basic tenets for organisational behaviour: 1) responsiveness towards customer's needs, 2) close monitoring of the competitor's actions, 3) facilitation of inter-functional coordination [20]. It is these three aspects embedded into the thinking, as well as the behaviourisms of the firms, that creates the solid ground for competitive advantage, delivering superior value, and subsequently sustainable growth. In figure 1 can be seen how the individual aspects interlink, in order to generate the culture and behaviour necessary for creating sustainable value. However, when altering or re-thinking a firm's strategy, these behaviourisms still have to be achieved. Now, in the literature there is evidence of strategy being an antecedent of market orientation [21], while others advocate that strategy is in fact a consequence of market orientation [22]. Gounaris et al. [23] highlights that market orientation represents the implementation of the marketing concept and its cultural orientation, including behavioural implications. They claim that market orientation focuses on organisational efforts of understanding the market and on developing strategies in response to market opportunities or threats. On the other spectrum, market orientation helps firms to identify and respond to changes in their environment and in customer demands[22]. In our opinion, both apply, as they are 
functions of the other. Therefore, we believe a new strategy of an organisation should be in line with the aforementioned on creating a strategy that is customer driven, competition focused, and executed throughout all departments at play. This will lead to high performance of the organisations, leading to a competitive advantage and generating superior customer value. This, in turn, will lead to a specific organisational behaviour, practiced by all departments every day.

Table 1. Ten premises of $S-D$ logic.

\begin{tabular}{|c|c|c|}
\hline FPs & Foundational premise & Comment/explanation \\
\hline FP1 & $\begin{array}{l}\text { Service is the } \\
\text { fundamental basis of } \\
\text { exchange }\end{array}$ & $\begin{array}{l}\text { The application of operant resources } \\
\text { (knowledge and skills), "service", as } \\
\text { defined in S-D logic, is the basis for all } \\
\text { exchange. Service is exchanged for } \\
\text { service. }\end{array}$ \\
\hline FP2 & $\begin{array}{l}\text { Indirect exchange } \\
\text { masks the fundamental } \\
\text { basis of exchange }\end{array}$ & $\begin{array}{l}\text { Because service is provided through } \\
\text { complex combinations of goods, } \\
\text { money, and institutions, the service } \\
\text { basis of exchange is not always } \\
\text { apparent. }\end{array}$ \\
\hline FP3 & $\begin{array}{l}\text { Goods are distribution } \\
\text { mechanisms for service } \\
\text { provision }\end{array}$ & $\begin{array}{l}\text { Goods (both durable and non-durable) } \\
\text { derive their value through use - the } \\
\text { service they provide. }\end{array}$ \\
\hline FP4 & $\begin{array}{l}\text { Operant resources are } \\
\text { the fundamental source }\end{array}$ & $\begin{array}{l}\text { The comparative ability to cause } \\
\text { desired change drives competition. }\end{array}$ \\
\hline
\end{tabular}

\begin{tabular}{|c|c|c|}
\hline FPs & Foundational premise & Comment/explanation \\
\hline & $\begin{array}{l}\text { of competitive } \\
\text { advantage }\end{array}$ & \\
\hline FP5 & $\begin{array}{l}\text { All economies are } \\
\text { service economies }\end{array}$ & $\begin{array}{l}\text { Service (singular) is only now } \\
\text { becoming more apparent with } \\
\text { increased specialization and } \\
\text { outsourcing. }\end{array}$ \\
\hline FP6 & $\begin{array}{l}\text { The customer is always } \\
\text { a co-creator of value }\end{array}$ & Implies value creation is interactional. \\
\hline FP7 & $\begin{array}{l}\text { The enterprise cannot } \\
\text { deliver value, but only } \\
\text { offer value } \\
\text { propositions }\end{array}$ & $\begin{array}{l}\text { Enterprises can offer their applied } \\
\text { resources for value creation and } \\
\text { collaboratively (interactively) create } \\
\text { value following acceptance of value } \\
\text { propositions, but cannot create and/or } \\
\text { deliver value independently. }\end{array}$ \\
\hline FP8 & $\begin{array}{l}\text { A service-centered } \\
\text { view is inherently } \\
\text { customer orientation } \\
\text { and relational }\end{array}$ & $\begin{array}{l}\text { Because service is defined in customer- } \\
\text { determined benefit and co-created it is } \\
\text { inherently customer orientation and } \\
\text { relational. }\end{array}$ \\
\hline FP9 & $\begin{array}{l}\text { All social and } \\
\text { economic actors are } \\
\text { resource integrators }\end{array}$ & $\begin{array}{l}\text { Implies the context of value creation is } \\
\text { networks of networks (resource } \\
\text { integrators). }\end{array}$ \\
\hline FP10 & $\begin{array}{l}\text { Value is always } \\
\text { uniquely and } \\
\text { phenomenological } \\
\text { determined by the } \\
\text { beneficiary }\end{array}$ & $\begin{array}{l}\text { Value is idiosyncratic, experiential, } \\
\text { contextual, and meaning laden. }\end{array}$ \\
\hline
\end{tabular}

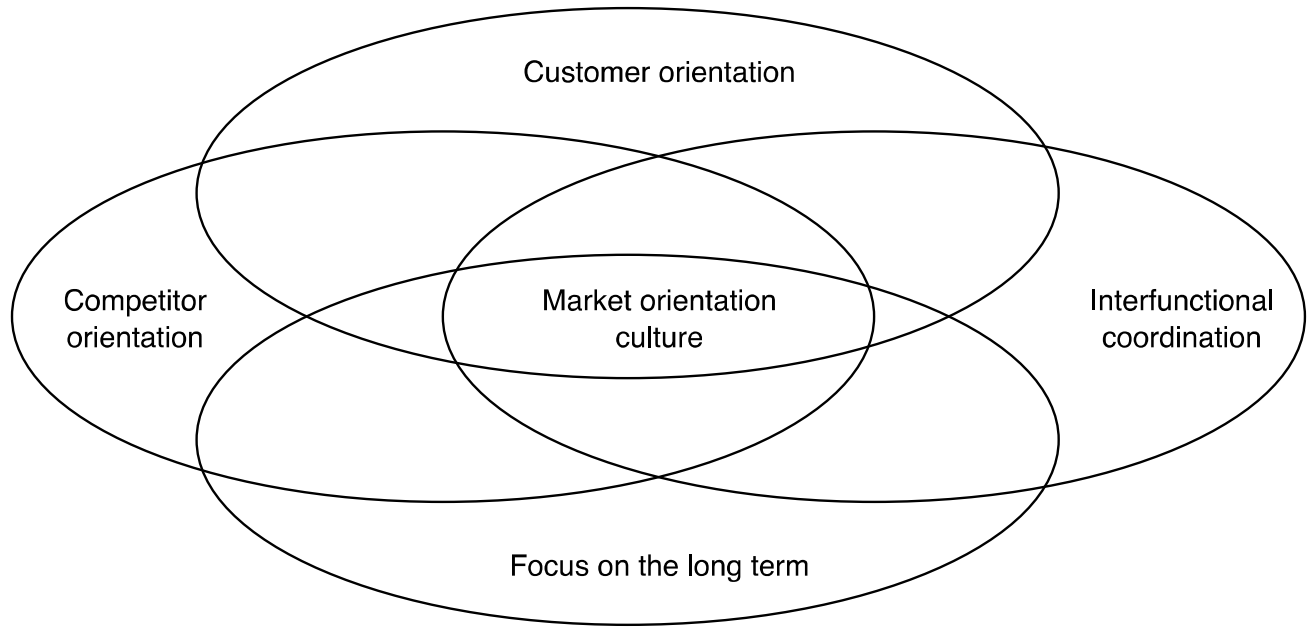

Figure 1. Market orientation.

\subsection{Service Dominant Logic and Co-Creation of Value}

Our second and third concept implementing such a strategy comes from the notion under business scholars and practitioners, that it is clear that competitive advantage can be enhanced through service [24]. Furthermore, there is clear evidence of a link between competitive advantage and enhanced performance [6,25]. However, even though managers are motivated to perform and are aware of this connection between service, competitive advantage and firm performance, they often fail to implement that knowledge [2]. Building on the market orientation concept, customers must have a central position within the business strategy of a firm in which co-creation should be key. By co-creating the function, as well as the meaning of its experience, the customer co-constructs value for himself [26]. Also Normann and Ramirez [27] point out that the customers are, in this perception, active contributors to value creation. Grönroos [5] even extends this to the point that suppliers only create the resources or means to make it possible for customers to create value for themselves. So, customisation and cocreation should make up an important part of the future developed business strategy. This notion is in line with the concept of service-dominant logic, which is a conceptual framework by which we can view exchanges, markets, enterprises, and competition through service [3]. Servicedominant logic is based on an understanding of the interwoven fabric of individuals and organisations that are bonded together into networks and societies, specialising in 
and exchanging the application of their skills for the applied competence they need for their own well-being. It is thus based on the philosophy to commit into collaborative processes with customers, partners and employees [3]. In contrast, goods-dominant logic, which has been the focal concept for many years, views units of output as the central components of exchange, in which a competitive advantage was seen to be a function of utility maximisation through embedding value in products by superior manipulation of the four P's, with an assumed passive consumer in mind [3]. In this view, services are considered, almost simultaneously, both a type of product and something of a fifth $\mathrm{P}$ [28]. Service-dominant logic, on the other hand, is built on ten premises, from which it can be deduced that S-D logic advocates viewing the customer as a resource that is capable of acting on other resources, and as a collaborative partner who co-creates value with the firm [29] (See table 1). In this view, the four P's represent a different proposition, i.e. products are viewed in terms of service flows. The service is directly or indirectly provided through an object; promotion is reconstructed towards conversation and communication with the customer; price is replaced with a value proposition created by both sides of the transaction; and place is replaces with value networks and processes [29]. Whereas in G-D (goods dominant) logic it is the tactical manipulation of the four P's that provides the dimension by which to compete, S$\mathrm{D}$ logic states that it is not the products but the benefit available through the service of the provider, as customers purchase solutions [30]. Following the interpretations of the four P's, S-D logic recognises that firms can only make a value proposition, and that value itself is a continuous process that unfolds over time as customers take part in the value creation process [31]. The worth of these value propositions consists of multiple elements. Sawhney [30] states that this can be conceptualised as the sum of the merit of individual products that make up the solution, plus the value of marketing or operational integration coming from the solutions vendor, in addition to the value coming from the customisation for the specific needs of the customer and context. Comet et al. [32] names as characteristics that solutions are co-created by a customer and a supplier, and cover all aspects of the relationship. Solutions are customised in one or more of the following aspects: design, assembly, delivery, operation or pricing, and solutions involve the supplier taking managed risks and therefore often include performance contracts. In comparison to G-D logic, in S-D logic the core moves from answering the customer's operational needs to helping a customer to develop his business in existing or new markets [31]. This shift can be done through a set of customer-supplier relational processes comprising customer requirement definition, customisation and integration of goods or services and their deployment, and post-deployment customer support [33].

Now, in order to turn these notions into strategy, these premises have to be turned into a product service offer. In general, product service strategies have been found to influence overall client satisfaction [34], facilitate new product adoption [35], and strengthen the customer's confidence and the supplier's credibility [36]. Customers do want to take advantage of a supplier's know-how to derive more worth connected with the use and performance of products [37]. In general there are two types of service transition strategies: those that support the supplier products, and those that support the client's action [38]. Examples of the latter one consist of financing, process-oriented training, and business-oriented consulting. In order to create a sustainable competitive advantage, companies that want to differentiate themselves must provide advanced services that offer increased merit through customisation and a proactive sensing of client expectations [39]. In other words, firms must transition towards services tied to the customer's process [38]. However, this should not entail taking customer's requirements as a given, but rather as a starting point for a process of co-creating the solution [4]. These solutions consist of both strategic as well as consultative business activities [40]. Building on the above-elaborated concepts, in our opinion it is clear that the to-be developed strategy model should be focussed on the interaction with customers, and having the proposition of co-creating value. Business consulting will be a large portion of the service proposal, as well as training on product and sales level, in order to not forgo on competition and market needs. However, both market orientation, as well as S-D logic is worthless if it is not grounded substantially into the behaviour of the human capital of the firm.

\section{Mind-Set and Competences}

As one can imagine, the concepts provided in the above paragraphs consist of several challenges in converting organisations from a more or less goods-dominated logic, to a more service-dominated marketing logic. As mentioned above, in order to reach optimisation of the concepts of market orientation and service-dominant logic, it is important that employees in all departments have a change in mind-set, from delivering goods towards delivering service proposals. In the current dynamic business environment it is unrealistic for a firm, and therefore its employees, to remain static in their value propositions or offered services; hence, service innovations are instrumental. In order to act upon these service innovations, the modifications are dependent on a collection of competences, which the firm can continually renew, create, integrate, and transform [3]. However, there is one skill within S-D logic that is pivotal to the firm in order to reach a competitive advantage, which is collaborative competence. This competence will assist in the development of two additional abilities needed in these business environments. The first is absorptive competence, which is the ability to be able to comprehend the important trends and know-how, from the external environment. This ability will assist in transforming these external aspects into important resources the firm can draw upon for support. Collaborative competency will aid a firm in absorbing new information and knowledge from partners or improve its absorptive 
competence [3]. The second meta-competence is adaptive competence, which is the ability of an organisation to adjust to changing circumstances. By developing collaborative competency, the company is able to use its partner firms as mechanisms for adapting to change, brought about by complex and turbulent environments, and consequently improve its adaptive competence [3]. The main challenge with installing S-D and market-oriented strategies is that a solution orientation is usually seen to imply a change in attitudes and conventional ways in thinking [4]. Emphasis in this process should be placed on understanding the customers' business requirements and operating environment, and finding ways to better connect with these processes. Transforming these capabilities at the customer interface is expected to be one of the most crucial challenges involved in transitioning towards solutions [41]. As installing such a mind-set means a change in orientation away from product focus, new capabilities need to be developed, but also a cultural shift is required within the organisation [42]. A critical caveat on performance is that it is also important to understand that the value proposal must address the needs of both the initial as well as the goal customer or consumer [42]. Within this new mind-set, it is important to recognise that in S-D logic goods do not form the focal point of exchange, but perform a service-delivery role in the customer's own value creation process [4]. The new, prospective developed, strategy model has to take into account these necessary alterations of daily processes and business conversations. It is therefore important to not merely impose this strategy, but have all stakeholders in place in providing service solutions towards customers, in order to have a common understanding and perspective of the market.

\section{Conclusion}

A new model of strategy will not emerge spontaneously from the obsolete legacy of the industrial age. Companies must, therefore, design a new model holistically; using new principles that take into account the way professionals create valuable content [43]. In this paper we have reasoned on the central premise that in order for a competitive advantage to create sustainable business growth to the firm, this firm needs to structure itself in a way that optimises customer differentiation and value creation [4]. Taking the concepts of market orientation and service-dominant logic as central points within the creation of the new strategy model, it is clearly diverting from the utilisation of existing mind-sets. Every company wants to find the way in which it can grow, without having to compete on limited elements such as price, and be better than the opposition. As Foppen [44] stated, a successful strategy is not created at the top as a formal method, but depends on the emerging strategies in order to lead to a realisation. This implies the need for interaction within companies, their direct environment, and the creation of networks in which knowledge can be developed in order for these emerging strategies to be capitalised in realising the firm's intended strategy. Firms that are able to combine the discussed elements and put effort in it to create success will viably create, in our perception, value and sustainable growth. These firms are able to create blue oceans instead of fighting in the red oceans [45]. This process is not easy, as it incorporates all of the fundamental processes in companies, but by addressing these processes as well as acting upon them, these firms will create flourishing strategic models, or blue oceans, which will grant them survival in the modern business world. Development is the key word in accomplishing this status; development of the internal structure, -talents and -leadership. However, in creating an environment in which the firm can do business in a different manner than competition and therefore competes on a different level, the mind-set of this firm and its dynamic resources has to change. As Kim and Maugorgne [45] denominate this as finding the blue ocean while competing in the red ocean, firms have to actively find and change towards this blue ocean. In our opinion acting on the concepts of market orientation and service-dominant logic, we believe this mind-set will change towards the needed aspects and characteristics, and this will in turn attain an admirable competitive position in order to sustainably grow.

In order to move on to the explained new strategy, organisations can not remain acting in the same manner as they have before. It is important to integrate this strategy within organisations, and more importantly its mind-set, into actions affecting the market. Therefore, in order to become successful by this strategy, the concepts have to be given content. It is therefore our recommendation that all stakeholders will engage in customer conversations, next to customer analysis, to determine the specific needs of each customer, in order to be able to know how to differentiate the proposition on these elements. In starting the dialogue together with the customer, it will become more evident which message to convey, and how to build the differentiated value proposition for the specific customers. This is the main task for the marketers and sales people involved with these product lines and their respective customers, in order to generate co-creation and value-added business. From our side, this automatically means to nurture the strategy, steer and evaluate the progress, and also to act on certain aspects in order to generate maximal output of this strategy.

\section{References}

[1] Donaldson, L. (1996), The normal science of structural contingency theory in Handbook of organization studies, Clegg, S.R., Hardy, C. \& Nord, W.R., Sage: London, pp. 5776

[2] Bharadwaj, S.G., Varadarajan, R.P. \& Fahy, R. (1993), Sustainable competitive advantage in service industries: A conceptual model and research propositions, Journal of Marketing, Vol. 57-10, pp. 83-99

[3] Lusch, R.F., Vargo, S.L. \& O'Brien, M. (2007), Competing through service: Insights from service-dominant logic, Journal of Retailing, Vol. 83-1, pp. 5-18 
[4] Vargo, S.L. \& Lusch, R.F (2004), Evolving to a new dominant logic for Marketing, Journal of Marketing, Vol. 68-1, pp. 1-17

[5] Grönroos, C. (2006), Adopting a service logic for marketing, Marketing Theory, Vol. 6-3, pp. 317-334

[6] Porter, M.E. (1985), Competitive advantage, The Free Press, New York, NY

[7] Slater, S.F. \& Narver, J.C. (1992), Superior customer value and business performance: The strong evidence for a market driven culture, Working Paper, Report No. 92-125, Marketing Science Institute, Cambridge MA

[8] Teece, D.J. (2010), Business models, business strategy and innovation, Long Range Planning, Vol. 43, pp. 172-194

[9] Dyer, J.H. \& Singh, H. (1998), The relational view: cooperative strategy and sources of international competitive advantage, Academy of Management review, Vol. 23, pp. 660679

[10] Gulati, R., Nohria, N. \& Zaheer, A. (2000), Strategic networks, Strategic Management Journal, Vol21-3, pp. 203-215

[11] Normann, R. (2001), Reframing business: When the map changes the landscape, Wiley, Chichester, New Sussex

[12] Deshpande, R., Farley, J.U. \& Webster, F.E. (1993), Corporate culture, customer orientation, and innovativeness in Japanese firms: A quadrad analysis, Journal of Marketing, Vol. 57-1, pp. $23-27$

[13] Slater, S.F. \& Narver, J.C. (1994), Does competitive environment moderate the market orientation performance relationship?, Journal of Marketing, Vol. 58-1, pp. 46-55

[14] Day, G.S. \& Wensley, R. (1988), Assessing advantage: A framework for diagnostic competitive superiority, Journal of Marketing, Vol. 52-4, pp. 1-20

[15] Webb, D., Webster, C. \& Krepapa, A. (2000), An exploration of the meaning and outcomes of a customer-defined market orientation, Journal of Business Research, Vol. 48, pp. 101112

[16] Kohli, A. \& Jaworski, B.J. (1990), Market orientation: The construct, research propositions, and managerial implications, Journal of Marketing, Vol. 54-4, pp. 1-18

[17] Shapiro, B.P. (1988), What the hell is market oriented?, Harvard Business Review, Vol. 66-11, pp. 119-125

[18] Zaltman, G., Duncan, R. \& Holbek, J. (1973), Innovations and organizations, New York: John Wiley \& Sons

[19] Slater, S.F. \& Narver, J.C. (1995), Market orientation and the learning organization, Journal of Marketing, Vol. 59-7, pp. 6374

[20] Narver, J.C. \& Slater, S.F. (1990), The effect of a market orientation on business profitability, Journal of Marketing, Vol 54,4 , pp. $20-34$

[21] Lukas, B. (1999), Strategic type, market orientation and the balance between adaptability and adaptation, Journal of Business Research, Vol. 45, pp. 147-156

[22] Santos, M., Sanzo, M., Alvarez, L. \& Vazquez, R. (2005), Effects of market orientation on business strategic behaviour, Journal of Strategic Marketing, Vol. 13, pp. 17-42
[23] Gounaris, S., Avlonitis, G. \& Papastathopoulou, P. (2004), Managing a firm's behaviour through market orientation development: Some empirical findings, European Journal of Marketing, Vol. 38, pp. 1481-1508

[24] Karmarkar, U. (2004), Will you survive the services revolution?, Harvard Business Review, Vol. 82-6, pp. 100-108

[25] Hunt, S.D. \& Morgan, S.R.M. (1995), The comparative advantage theory of competition, Journal of Marketing, Vol. 59-4, pp. 1-15

[26] Lusch, R.F \& Vargo, S.L (2006), Service dominant logic as a foundation for a general theory in Service dominant logic of marketing: Dialog, debate and Directions, Armonk, NY, pp. 406-420

[27] Normann, R. \& Ramirez, R. (1994), Designing interactive strategy: From value chain to value constellation, John Wiley \& Sons, Chichester

[28] Booms, B.H. \& Bitner, M.J. (1981), Marketing strategies and organization structures for service firms in Marketing of services, Donnelly, J. \& George, W.R., American Marketing Association, Chicago, IL, pp. 51-67

[29] Vargo, S.L. \& Lusch, R.F. (2008), Service dominant logic: Continuing the evolution, Journal of the Academy of Marketing Science, Vol. 36-1, pp. 1-10

[30] Sawhney, M. (2006), Going beyond the product: Defining, Designing and Delivering customer solutions in Service dominant logic of marketing: Dialog, debate and Directions, Lusch, R \& Vargo, S.L. (2006), Armonk, NY, pp. 365-380

[31] Cova, B. \& Salle, R. (2008), Marketing solutions in accordance with the S-D logic: Co-creating value with customer network actors, Industrial Marketing Management, Vol. 37, pp. 270-277

[32] Comet, E., Katz, R., Molloy, R., Schadler, J., Sharma, D. \& Tipping, A. (2000), Customer solutions: From pilots to profits, Booz, Allen \& Hamilton Viewpoint

[33] Tuli, K.R., Kohli, A.K. \& Bharadwaj, S.G. (2007), Rethinking customer solutions: From product bundles to relational processes, Journal of Marketing, Vol. 71-7, pp. 1-17

[34] Burger, P.C. \& Cann, C.W. (1995), Post-purchase strategy - A key to successful industrial marketing and customer satisfaction, Industrial Marketing Management, Vol.24, pp. 91-98

[35] Frambach, R., Ward, J., Hutt, M \& Reingen, P (1997), Proactive product service strategies - An application in the European Health market, Journal of Marketing, Vol. 72, pp. 114

[36] Hawes, J. (1994), To know me is to trust me, Industrial Marketing Management, Vol. 23, pp. 215-219

[37] Vandermerwe, S. (1994), Service network structures for customer-oriented strategies in Marketing strategies for services: Globalization, client-orientation, deregulation, Kostecki, E., Pergamon Press, Oxford

[38] Mathieu, V. (2001), Product Services: From a service supporting the product to a service supporting the client, Journal of Business \& Industrial Marketing, Vol. 16-1, pp. 3958 
[39] Matthyssens, P. \& Vandenbempt, K. (2008), Moving from basic offerings to value-added solutions: Strategies, barriers, and alignment, Industrial Marketing Management, Vol. 37, pp. $136-328$

[40] Davies, A., Brady, T. \& Hodbay, M (2006), Charting a path towards integrated solutions, MIT Sloan Management Review, Vol. 47-3, pp. 39-48

[41] Johansson, J.E., Krishnamurthy, C. \& Schlissberg, H.E. (2003), Solving the solutions problem, McKinsey Quarterly, Vol. 3, pp. $116-125$

[42] Salonen, A. (2011), Service transition strategies of industrial manufacturers, Industrial Marketing Management, Vol. 40, pp. 683-690

\section{Biography}

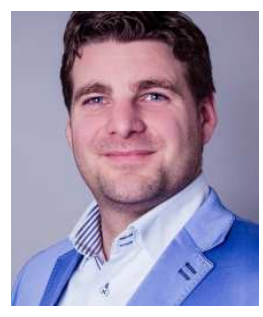

Ronald Roos is active as innovation marketer, focused on finding and initiating new market opportunities and collaboration with customers. He holds extensive experience in marketing and creating business ventures within the industrial sector. Intrigued by ideas at the intersection of innovation \& marketing, change management \& leadership, in order to sustainably create value, he is affiliated with the Research Centre of Employability and the master Personal Leadership in Innovation and Change from Zuyd University of Applied Sciences.

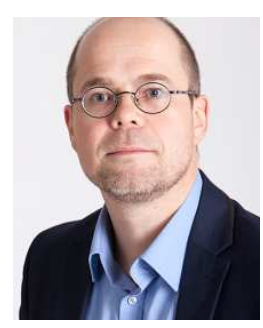

Jol Stoffers is professor of Employability (lector) at Zuyd University of Applied Sciences (Faculty of Management \& Law) in the Netherlands. He leads the Research Centre of Employability, and his research focuses on Employability (HRM), Leadership and Innovative Work Behavior. Next to that he is academic program manager of the master of Personal Leadership in Innovation and Change.

Jol Stoffers holds a $\mathrm{PhD}$ in Management Science from the Radboud University (Institute for Management Research), and an executive MBA (Master of Business Administration) of Maastricht University.
[43] Bryan, L.L. \& Joyce, C. (2005), The 21st-century Organization, The McKinsey Quarterly, No.3, pp. 20-29

[44] Foppen, J.W. (2011), Clusters and the new economics of competition, leadership, innovation, entrepreneurship, publicprivate ventures, Lecture Strategic HRM, Zuyd University, Netherlands.

[45] Kim, W.C \& Mauborgne, R. (2005), Blue Ocean Strategy, Harvard Business School Press, MA 